\title{
Surfaces
}

\section{On sex and Discipline}

\section{Robyn Wiegman}

Volume 5, 1995

\section{CULTURE AND INSTITUTIONS}

URI : https://id.erudit.org/iderudit/1064987ar

DOI : https://doi.org/10.7202/1064987ar

Aller au sommaire du numéro

\section{Éditeur(s)}

Les Presses de l’Université de Montréal

ISSN

1188-2492 (imprimé)

1200-5320 (numérique)

Découvrir la revue

Citer cet article

Wiegman, R. (1995). On sex and Discipline. Surfaces, 5. https://doi.org/10.7202/1064987ar

\section{Résumé de l'article}

Cet essai étudie les débats en cours entre les défenseurs de la théorie " queer " et les études gay et lesbiennes, afin de comprendre la façon dont chacune des positions articule l'agenda politique pour un changement social, institutionnel et disciplinaire. L'auteure considère que l'espoir utopique qui caractérise les deux perspectives critiques est un point commun très souvent ignoré dans la présentation des débats. Elle démontre d'ailleurs que ni la théorie " queer ", ni les études gay et lesbiennes, ne font actuellement suffisamment attention à la politique « locale » de l'institution, et elle dresse la possibilité d'un horizon politique en vue d'un changement institutionnel qu'on pourrait appeler " queering the academy".
Ce document est protégé par la loi sur le droit d'auteur. L'utilisation des services d'Érudit (y compris la reproduction) est assujettie à sa politique d'utilisation que vous pouvez consulter en ligne.

https://apropos.erudit.org/fr/usagers/politique-dutilisation/ 


\section{On sex and Discipline}

Robyn Wiegman, Associate professor

Rwiegman@ucs.indiana.edu

Indiana University

English and Women's Studies

Surfaces Vol.V.102 (v.1.0A - 29/11/1995)

Copyright for texts published in SURFACES remains the property of authors. However, any further publication should be accompanied by an acknowledgement of SURFACES as the place of initial publication.

ISSN: $1188-2492$

\section{ABSTRACT}

This essay examines the current debate between proponents of "queer theory" and "gay and lesbian studies" in order to understand the way each sets forth a political agenda for disciplinary and institutional social change. The author surmises that the utopian hope invested in each critical perspective evinces an affinity that is often overlooked in the way the debate is presented. Further, she argues that neither queer theory nor gay and lesbian studies currently pays adequate attention to the "local" politics of the institution, and she raises the possibility of a political horizon for institutional change which we might call "queering the academy."

\section{RÉSUMÉ}

Cet essai étudie les débats en cours entre les défenseurs de la théorie "queer" et les études gay et lesbiennes, afin de comprendre la façon dont chacune des positions articule l'agenda politique pour un changement social, institutionnel et disciplinaire. L'auteure considère que l'espoir utopique qui caractérise les deux perspectives critiques est un point commun très souvent ignoré dans la présentation des débats. Elle démontre d'ailleurs que ni la théorie "queer", ni les études gay et lesbiennes, ne font actuellement suffisamment attention à la politique "locale" de l'institution, et elle dresse la possibilité d'un horizon politique en vue d'un changement institutionnel qu'on pourrait appeler "queering the academy".

In a fit of bad taste, I almost titled my paper "to queer or not to queer," partly because I kept hearing the phrase as if spoken in a dialect where "queer" shaded subtly into "care." I planned to use this shading to explore 
how so much of the controversy about the difference between lesbian and gay studies on one hand and this thing called queer theory on the other turned on the way each was perceived to care about and for gay and lesbian people. I thought I might suggest - without being sentimental about it, of course - that something about caring was at stake in the highly contentious conversations about this new discipline's disciplinary shape and, further, that this caring was, ironically, not simply a good thing. By foregrounding the sense of sound (as opposed, say, to sight), I was also going to nuance my talk toward questions of voice, authority, and critical speech - questions that for most commentators are central to the growing war of disciplinary definition between "gay and lesbian studies" and "queer theory."

But I was having a problem with the way all this shading was working itself, rhetorically speaking, out: for while the question of queering and caring was a distinction born of dialect, of sound that shaped and/or conflated meaning, the terms I am most interested in can't be stretched to any kind of aural effect. In no English dialect, after all, can I fantasize lesbian and gay as shading into queer, though it is easy enough to make a case that their contemporary currency, born of controversies about politics, identity, and disciplinarity, always situates them within earshot, ambitious actors vying for the same role in an overcrowded (and underfunded) casting scene. But I anticipated an objection to the way my rhetoric confused itself, moving from metaphors of sound to those of space, to that final insult, performance, now a theoretical cliche.

At the same time, however, confusion seems to be a necessary part of the point - at least a symptom of the metaphoric messiness and conceptual lack of cohesion that accompanies the debate about queer theory and lesbian/gay studies. To begin to explicate this debate is to take up the question of political caring on one hand (how does each care for gay and lesbian people?) and of disciplinary and institutional intervention on the other (what might it mean to queer the academy?). Both of these questions are intimately linked to issues of identity: What will the identity of sexuality studies be? In whose name will we speak? What institutional rewards and transformations do we seek? To pursue these questions means entering the debate, now so politically and personally intense; its explication requires several takes.

\section{Take 2}

In a recent essay in English Studies in Canada, Eric Savoy offers what is now a well-voiced skepticism toward the theoretical tasks and adventures of "queer theory." For him, the poststructuralist interrogation of identity (which might be said to be the defining characteristic of "queer theory") threatens in personal, political, and institutional ways lesbians and gays themselves. In explaining his position, Savoy uses three phrases that most interest me: "at the very moment"; "who is being served"; and "definitional power over our own sexualities." He writes:

it is supremely ironic that at the very moment when gay men and lesbians have acquired a genuine presence and legitimacy in the 
academy, we are being asked to abandon this hard-won position for, and to concede the superior theoretical sophistication of, a project that views us - and the desire to occupy a political "identity" — from a suspicious, critical distance ... [I]t is necessary to ask precisely who is being served by such critical inquiry. If the project of locating the sites of queerness and defining its transgressive manoeuvres is completely dissociated and bracketed off from gay and lesbian identity politics, then its seems inevitable that self-identified gays and lesbians will lose what we may currently have, that is, the definitional power over our own sexualities and cultural productions ... [I]t is necessary to inquire whether the loss of lesbian and gay "coherence" entails a coterminous and systematic loss of both political integrity and political self-determination. $(131,134)$

For Savoy, the interrogation of identity that accompanies the post-humanist project of contemporary queer theory - the very lack of a subject implied in the term - stands in an antithetical and dangerous relation to the social and institutional gains of gay and lesbian politics. "At the very moment" foregrounds this danger as one of historical conjuncture, echoing similar laments toward poststructuralist theory from both feminist and AfricanAmericanist discourses. As a kind of conspiracy theory, this perspective reads poststructuralism as inherently conservative, a historical emergence aimed at recuperating the hard-won political gains of identity-based social movements by undermining the genuine presence and institutional legitimacy that has accompanied the founding of disciplinary fields in a variety of identity names (gay and lesbian; African-American, etc.). From this perspective, liberation from homophobic and heterosexist social and institutional constraints is linked to disciplinary activity which, in the institution's vocabulary, is shorthand for saying that with lesbian and gay studies, gays and lesbians will be bastards no longer.

But to become sons and daughters of the institution is itself a pricey game. And too often the disciplinary legitimacy of gay and lesbian studies goes the way of other identity-based representational practices: presence and legitimacy accrue to those within the category most unmarked by other categories of social difference. The anxiety that queer theory is a conspiracy against those who have achieved for their historical marginality greater cultural and institutional acceptance might thus be read another way: as a lament that the historical race and gender privilege of gay white men within the identity collaboration of gay and lesbian is not much of a privilege any longer.

Indeed, for various queer theorists, the dissolution of identity as the means for disciplining the borders of sexuality studies actually undoes social hierarchies, and furthermore it begins to dismantle the kind of recuperative representative identity politics that the academy, like other institutions in North America, have in the past 15 years begun to rely upon: where political identities are rendered as commodities and we can consume ourselves according to the triumphant illusion that legitimacy and presence are what we have gained. In an unpublished essay, Judith Roof refers to lesbian and gay studies as a trademark in order to question the strategy of discipline 
being offered when the consolidation of identities serves as the institutional trajectory of a group's political intent. In an economy of commerciallydefined categories, she says, reliance on an identity relinquishes the field's potential to call into question the logic of categorical consumption itself. In such institutional pluralism, gay and lesbian studies simply stakes a commodity claim in a market that seeks differentiation to "democratize" as equivalent a variety of groups, identities, categories, knowledges, and institutional locations that are in no way politically equivalent at all. 1 In short, such a disciplinary maneuver is a peace-keeping activity that patrols the borders where the other is allowed (and not liberated) to live.

The phrase "who is being served" refracts the relationship between identity and institutional transformation in another way. While it continues to locate the political stakes of interrogations of sexuality and institutional reconfigurations of knowledge in subject-based modes of legitimation, it seems to assume that the political effects of a discourse cannot only be predicted, but guaranteed from the outset: subjects have the self-conscious determination to know how their political cares will be greeted and/or feared. In this figuration of queer theory as the appropriating other of gay and lesbian institutional space and historical discourses, Savoy establishes an oppositional relationship through which queer theory's refusal of identitybased modes of legitimation is interpreted as an inherently conservative agenda.

Further, he suggests that the ascription of the political project of institutional intervention in the name of the people being served will guarantee that those effects will be progressive and not oppressive. The question of "who is being served" does not, then, have to be turned toward lesbian and gay studies - but it is precisely this turn that might begin to reveal the ways in which legitimacy has functioned according to the logic of minority: authority and visibility accrue to those within the identity category most socially empowered according to race, gender, class, and nationality. If queer theory displaces the legitimacy of various gays and lesbians in academia, it may do so to dismantle the recuperative representative identity politics that the academy, like other institutions in North America, have in the past 15 years begun to rely upon: where political identities are rendered as commodities and we can consume ourselves according to the triumphant illusion that legitimacy and presence are what we have gained.

Let me interrupt myself here to say that queer theory is not going to be held up, in the remaining minutes of this talk, as the great enlightenment. After all, why would I want to undo the clear sense of empowerment that Savoy is claiming for us - his notion that gays and lesbians have gained a certain degree of "definitional power over our own sexualities and cultural productions," even if my desire to associate with such a phrase means from at least some queer theoretical perspectives that I too need to read more Foucault? The rhetoric of empowerment promotes an important kind of political seduction and while we might understand Savoy's framing of that seduction to dwell within the determinants of the liberal humanist subject, it is not clear to me that any of us, subjectively speaking, have found a way to dwell elsewhere. For this reason, it might be useful to try to describe the relationship between queer theory and gay and lesbian studies less 
oppositionally than Savoy and others have done; both share a related, though differently configured, political hope arising from the contradictions that adhere to the constitution of gay, lesbian, dyke, bi, queer, etc., subjectivities, and neither, finally, begins to deal adequately with the political project of queering the academy.

\section{Take 3}

To work out what I am talking about here takes some backtracking. One of Savoy's laments against the ascendancy of queer theory is its difficulty in marshalling a political vocabulary for institutional intervention. Identitybased figurations, within the developed rhetoric of civil rights and minoritized inclusion in the twentieth century, affirm a political agenda, raising issues of visibility and disciplinary study as the achievement of a progressive political intent. Queer theory's interrogation of identity and modernity seems implicitly to challenge such an agenda - a challenge that is all the more striking precisely because of the absence within it (and in U.S. left discourses more widely) of an equally developed alternative rhetoric of political transformation. It is not, in other words, that queer theory lacks politics, but that its critique of the rhetoric of twentieth-century social struggle signals simultaneously a historical defeat (of the logic of identity as inherently, unquestionably, politically progressive) and a utopic regeneration (of the possibility for political change in the realm of sexuality).

The question implicit in Savoy's argument then, "to what extent does the queerness of queer theory challenge or change the institutional life of those who live within it under the sign of 'lesbian and gay'?" is crucially important, and it has, I think, two answers. On one hand, we must say "very little" that is, the theoretical articulation of the queer has not yet attended to issues of institutional life, to the materialist relations in which sexualities, no matter how theoretically slippery, non-binary, and indeterminate, are nonetheless codified and overseen. On the other hand, we must answer the question with another question, which is: "What would it mean to queer the academy, not as a disciplinary conversation but as one that worked to transform the quotidian practices of sexual priorities and privileges across the variously social and public spaces of the institution?" I emphasize social and public spaces in order to turn our attention away from thinking that a kind of property location - a gay and lesbian studies program or interdisciplinary queer theory collaboration, even a queer minority affairs office - is the crucial answer to our political cares.

Gay and lesbian studies and queer theory may in fact share more than we have thought - that is, if we look at the utopian gesture that underlies the political horizon they each, however differently, construct. Queer theory, in arguing against categories of identity in the context of every identity category's contemporary commodification, along with its desire to leave the borders of the discipline more (as opposed to less) in dispute, expresses and enacts a political desire for disarticulating sexuality's prohibitive and prescriptive social constraints. This hope to undo the strictures of political discipline that adhere to and define subjectivities and bodies according to hierarchical sexualities is finally no more or less utopian than the hope 
invested in gay and lesbian studies to satisfy the desire to discipline the institution through self-defined gay and lesbian knowledges and political intent.

And it is for this reason - in the conjunction of a hope for the transformation of the social forms of sexuality's hierarchical inscriptions that we might begin to consider how the debate over the identity of the political project of institutional intervention sheds little light on the practices of the institution itself. I am talking here about ideological and material practices, specifically those forms of social practices that turn on the presumptions and privileges of heterosexuality, that protective enclave that, as Savoy and others worry, often turns out to be the comfort zone of queer intellectuals as well. Heterosexual privilege, as we all know, exists in social expectations and their formations - in the structure and practice of community that turns repeatedly to monogamously coupled, reproductive, heterosexual norms - norms that are increasingly identified as the "civil rights" needed to undo the various oppressions facing queers. How we might begin to talk about the bourgeois subjectivity that disciplines sexuality, not only in the formations of knowledge that inhabit the institution but in the institution's form of politics, both the "dominant" and our own, is a task I think worth pursuing. By this, I mean critiquing the way that the binary, compulsory, and altogether inadequate understanding of sexuality that conditions our social "reality" functions as the framework for and effect of institutional notions of social organization and intellectual community.

In this regard, the work of queering the academy is not accomplished with the hiring of queer theorists or scholars in the emerging field of gay and lesbian studies. It is not accomplished by the codification of sexuality as a distinct difference, one whose institutional positioning can be modelled on those other and often analogized disciplinary interventions of women's studies or African-American studies. It is neither homosexuality nor the sexually liminal of any form that must be uncloseted in order to attend to the sexual politics of the institution, but the compulsory practices and social organizations of heterosexuality itself. 2 This work is not a matter of disciplinary shape, identity centered or not. Discipline, in short, cannot be the register in which we invest all - or the only (or perhaps any) - of our political cares. For this, we have to think of other horizons, beginning in the seemingly untheoretical and often uninteresting and certainly unlauded places of the classroom and committee meeting room, in curricular reviews and university policy struggles, in structures of social engagement and forms of intellectual community. Such political work does not herald the kind of spectacular party that post-Stonewall gay and lesbian pride displays have provided. There will be no march on Washington, not a single tee shirt. The political work of queering the academy, no matter how you may define your disciplinary priority, is more local, more institutionally specific, less overt, and perhaps finally more crucial (certainly less consumptive) than that. 


\section{NOTES}

1See "Buckling Down and Knuling Under: Discipline or Punish in Lesbian and Gay Studies, "Who Can speak? Authority and Critical Identity, eds. Judith Roof and Robyn Wiegman (Urbana: University of Illinois Press, 1995) : 180-192.

2By "Social organizations of heterosexuality," I mean those practices of social bonding and community building based on heterosexual norms which means that lesbians, gays, and bisexuals, along with heterosexuals, can be participants. 